International Review of Research in Open and Distributed Learning Volume 16, Number 4

October - 2015

\title{
How Factors of Personal Attitudes and Learning Environments Affect Gender Difference toward Mobile Distance Learning Acceptance
}

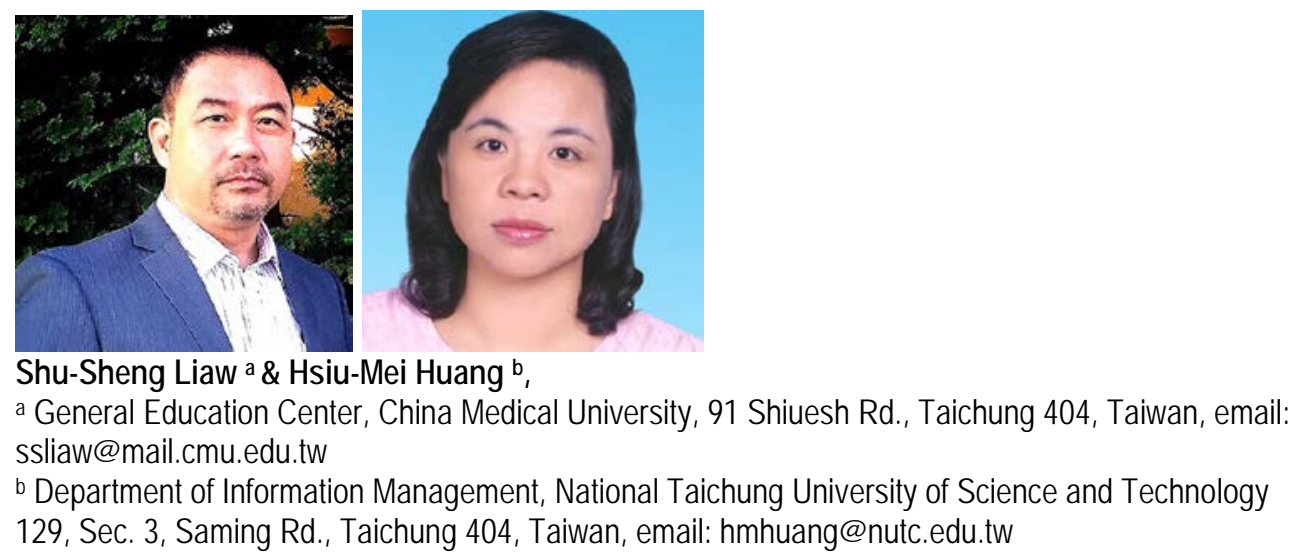

\section{Abstract}

Mobile technology for learning empowers the shift from traditionally pure instructor-centered classroom teaching to fully learner-centered educational settings. Although mobile learning (mlearning) accessing Internet resources anytime and anywhere and it may cause gender difference toward it; thus the issue of the relationship between gender perspectives and m-learning environments has been a controversial topic. Therefore, the main research objective of the research is to explore gender differences toward APP-based, m-learning environments. Subjects of the study were selected university students who had already used an APP-based, m-learning system for one month. A total of 159 valid questionnaires were collected and were split evenly between female and male Taiwan university students. The statistical analyses lead to significant conclusions. Both female and male learners have highly positive perceptions toward m-learning. Additionally, the proposed research model is an acceptable conceptual model for investigating female and male learner attitudes. Furthermore, factors of personal attitudes and learning environments affect gender difference toward m-learning acceptance.

Keywords: Mobile Learning, Social Network Interaction, Social Cognitive Theory, Gender Difference, Learner Attitudes, APP-Based Mobile Learning Environments. 


\section{Introduction}

Advanced computer and communication technologies now allow learners to exploit the potential learning effects of mobile devices for educational purposes. Mobile technology could facilitate human social interaction with each other and access to Internet resources anytime and anywhere. Indeed, the growth of mobile devices, such as smart mobile phones, e-books, and tablet PCs, has attracted the attention of educators and researchers (Crompton, 2013; Mcconatha, Praul \& Lynch, 2008; Motiwalla, 2007). The massive infusion of computing portable devices and rapidly improved Internet capabilities has influenced the quality of higher education; especially for distance education. In other words, mobile learning environments are considered as important and impressive factors in achieving the learning competencies and enhancing competitive advantages. It means that m-learning (mobile learning) is a pedagogical arsenal to support students as they navigate the options available in the expanding world of distance learning.

On the other hand, the issue of the relationship between gender perspectives and m-learning has been a controversial topic within the debate on educational technology culture in university campuses. In a broader context, gender is considered a basis to explain the inequalities and identities in our society. Jung (2012) confirmed that gender differences in the learners' perceptions toward educational technology; especially distance learning, should be considered in developing, delivering, and applying educational technology. In the background of computer and communication technologies, the literature recognizes that gender is an element for understanding the differences in user perceptions and attitudes toward technology adoption; especially for learning purposes. Jung (2012) also stated "Asian DE (Distance Education) providers should consider these gender differences when designing their courses and support systems." (p.21)

With regard to m-learning environments, does gender affect how learners adopt mobile devices to provide learning effects efficiently and effectively? Indeed, it is necessary to be investigated in this research. Okazaki and Renda dos Santos (2012) stated gender affected some of the causal relationships among learners' attitudes (i.e. perceived self-efficacy and perceived anxiety), social network interaction, perceived usefulness, and learners' behavioral intention toward e-learning. Previous research (Carr, 2005; Okazaki \& Renda dos Santos, 2012; Ong \& Lai, 2006) proposed that female learners had greater reliance on ease of use due to their lower level of computer literacy or computer experience when male learners had greater emphasis on perceived usefulness in determining behavioral intention toward learning technology. Therefore, understanding how gender differences influence the causal relationship toward m-learning adoption is a critical issue in distance learning field.

The main research objective of this research is to explore gender difference of attitudes toward APP-based m-learning environments. Specifically, the research is to survey the gender perspectives about female and male university students' perceptions toward using APP-based, mlearning environments. Indeed, based on an approach of social cognitive theory, this research 
tries to figure out gender perspectives toward APP-based m-learning acceptance. We will investigate the causal relationship among learner attitudes that include how personal attitudes (such as self-efficacy, self-regulation, and anxiety) affect learning environmental factors (such as perceived ease of use, usefulness, and social network interaction); we will also investigate how learning environmental factors influence behavioral acceptance. Thus, the following section will review existing bodies of work on effects of m-learning, gender issues of technology-based learning, and users' attitudes toward m-learning. Section three will propose a research model and research hypotheses. Next, section four will introduce the APP-based, m-learning system for this research, and section five will describe our methodology that explains participants and survey questionnaire. The research results will be presented in section six and the last two sections will discuss our findings, conclusions, and suggest future research.

\section{Literature Review}

\section{The Learning Effects of M-Learning}

Nowadays, with mobile technology, learners are able to learn anything, at any place, and any time. The available mobile devices could empower the shift from traditionally pure instructorcentered classroom teaching to fully constructivist learner-centered educational settings away from the classroom. M-learning is independent of the location of the learner, as the mobile device literally travels with its owner. It means that m-learning usually provides interaction functions to allow learners to control (or search) information flow and/or social communication with each other through handheld devices for distance learning.

The term m-learning has different meanings for different communities; it covers a range of use scenarios including e-learning, online learning, and distance education, as well as focusing on learning with mobile devices (Crescente $\&$ Lee, 2011). Mobile devices could offer various available educational alternatives and advantages. Mobile learners have access to the same personal device on a 24/7 basis and these types of devices are permissible for use in a broad variety of environments. M-learning can be defined as "learning across multiple contexts, through social and content interactions, using personal electronic devices" (Crompton, 2013, p.4). Although we do not expect m-learning to fully replace formal classroom learning or other formal learning approaches, m-learning can complement and add value to the existing learning styles or learning models, especially for distance education. Meanwhile, m-learning, like other forms of e-learning, is also a collaborative platforms for learners and teachers. Content and instructional information being shared in m-learning environments is almost instantaneous among everyone using the same content, instruction, or platform, which leads to the reception of instant feedback and tips.

Based on the m-learning research findings of Liaw, Hatala, and Huang (2010), the major five applications of m-learning for learning effects are: educational content delivery application,

This work is licensed under a Creative Commons Attribution 4.0 International License. 
adaptive learning application, interactive application, individual application, and collaborative application. An educational content delivery application refers to creating m-learning platforms on mobile devices to provide various educational services for learning. An adaptive learning application tends to design learning environments in which content development tools are built to deliver learning content adaptively to mobile devices. Indeed, an interactive application tends to create mobile learning systems based on mobile devices, sometimes with other technologies such as personal computers, to increase interaction or communication among students and/or teachers. An individual application provides information and services via mobile devices to learners according to a learners' location and/or their needs. Finally, a collaborative application makes use of the available communication and interaction features of mobile devices to encourage joint learning activities. These five applications make m-learning a platform that could improve learning effects significantly.

\section{Gender Difference toward Educational Technology}

The gender gap in educational devices and technologies has interested educational scholars and researchers. Various perceptual factors associated with gender differences have been explored in previous research (Albert \&J ohnson, 2011; Chu, 2010; González-Gómez , Guardiola, Rodríguez \& Alonso, 2012; Ong \& Lai, 2006). The enormous growth of m-learning makes it necessary to reexamine the gender issue which has been an object of research in education. In this context, gender difference is a significant factor to take into account in m-learning environments. In other words, it is reasonable to posit that female and male learners have different perceptions toward m-learning environments.

Investigating the gender perspectives in learners' attitudes towards m-learning more thoroughly can assist researchers and educators in understanding how to consider gender when developing better m-learning platforms for learners. From previous research, Ong and Lai (2006) stated that men had more positive perceived usefulness affecting behavioral intention toward e-learning than women had. Furthermore, they also explained that men's rating of perceptions with respect to computer self-efficacy, perceived usefulness, perceived ease of use, and behavioral intention of using learning systems was higher than those of women. On the other side, research of Guardiola, Rodríguez, and Alonso (2012) showed that female students had higher perceived satisfaction resulting from using e-learning than male students had.

Albert and J ohnson (2011) argued that female students have more positive attitudes of perceived self-regulation, perceived ease of use, and perceived user-friendliness toward learning systems than male students had. This means that female learners had more positive perceptions toward learning technology than male learners. In their research Padilla-Meléndez, Aguila-Obra, and Garrido-Moreno (2013) stated that female learners' positive attitudes toward using learning systems could be affected by perceived playfulness while male learners' positive attitudes toward using learning systems could be influenced by perceived usefulness.

This work is licensed under a Creative Commons Attribution 4.0 International License. 
After examining previous studies (Albert \& Johnson, 2011; Chu, 2010; González-Gómez, Guardiola, Rodríguez \&Alonso, 2012; Ong \& Lai, 2006), we realize that while some studies stated male learners had more positive attitudes toward computer technology for learning purposes; some other studies argued that female learners had higher preference for applying educational technology to assist their learning activities. Therefore, in this study, we progress to investigate gender differences in using m-learning technology to further and better our understanding.

\section{Attitudes toward M-Learning Based on the SCT Approach}

The Social Cognitive Theory (SCT) represents a broad approach to understanding human behavior and advanced capacities for learning (Bandura, 1986). SCT considers the power of human agency in life's achievements, beliefs, and outcomes. Lin (2010) figured out that SCT is an accepted theory that provides a critical perspective in depth for investigating the reasons why individuals adopt certain behaviors. According to SCT, learning is affected by individual experience and individuals learn from the consequences of their own and others' actions as well as develop new cognitive structures for behavioral actions. Therefore, while individuals' actions produce positive outcomes, they tend to reinforce the cognitive structures, but when individuals past actions produce negative consequences, they will adjust their cognition to produce more positive outcomes. These produce rules of behavior that serve as guides in future situations. Furthermore, past experience serves to shape future actions via cognitive processes they engage when facing new contexts or environments (Wan, Wang, \& Haggerty; 2008).

Based on SCT, a model consists of three reciprocal interactive factors (Figure 1): personal, behavioral, and environmental. These three factors constantly affect each other (Wang \& Lin, 2007). The interactions that occur between personal and behavioral factors involve the person's thoughts and actions. Individuals imitate model behaviors learned by personally observing others, the environment or the media (Wang \& Lin, 2007). Additionally, the interactions that occur between behavioral and environmental factors involve both learners' behavioral reaction toward environments, and the learners' ability to change those environments (Wu, Tennyson, \& Hsia, 2010).

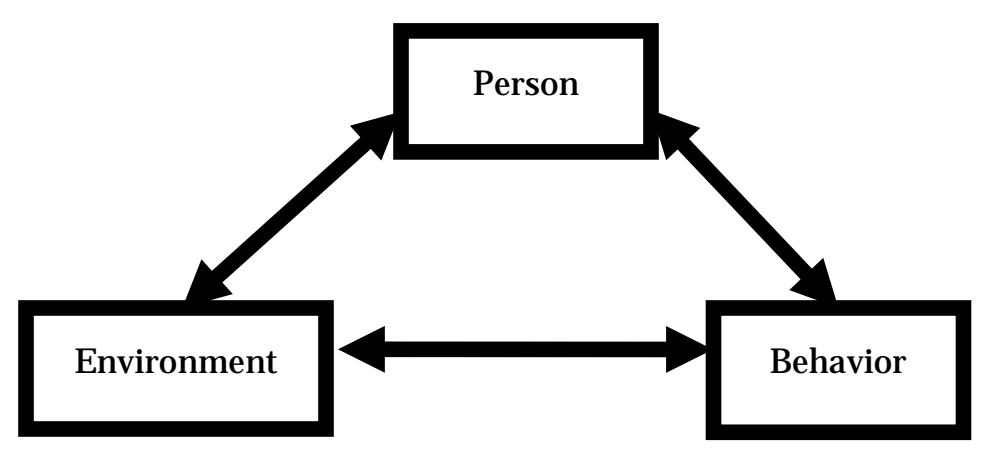

Figure 1: Social Cognitive Theory 
The approach of social cognitive perspective holds that successful self-regulated learners possess higher levels of motivation (personal influences), apply more effective learning strategies (behavioral influences) and respond more appropriately to situational demands (environmental influences) (Pintrich \& Schunk, 2002). From the research of Pintrich and Schunk (2002), the expectancy component may be conceptualized as the students' belief that they are capable of performing the task. For instance, self-efficacy is to refer that the students' perceptions of their capability to execute an action required achieve a particular outcome (Bandura, 1986). Bandura also found that self-efficacy strongly influences the choice of activity, the effort expended, the willingness to persist, and task accomplishment. Based on these results, learner personal factors, such as self-regulation and self-efficacy or even anxiety, will influence environmental factors and behavioral factors.

Additionally, based on the Liaw's (2008) and Liaw's and Huang's (2013) research, learner attitudes toward learning technology can be divided into three different tiers: the learner characteristics tier, the affective and cognitive tier, and the behavioral tier (as shown in Figure 2). The learner characteristics tier evaluates how personal factors (such as self-efficacy or anxiety) affect learner affective and cognitive factors. The affective and cognitive tier (such as perceived usefulness or perceived social communication) examines how affective and cognitive factors influence learner behaviors. And the behavioral tier is to find how the research model could predict learner behaviors to use technology for learning purpose. The results of Liaw (2008) and Liaw and Huang (2014) research provided an acceptable model to investigate learner attitudes toward e-learning or m-learning.

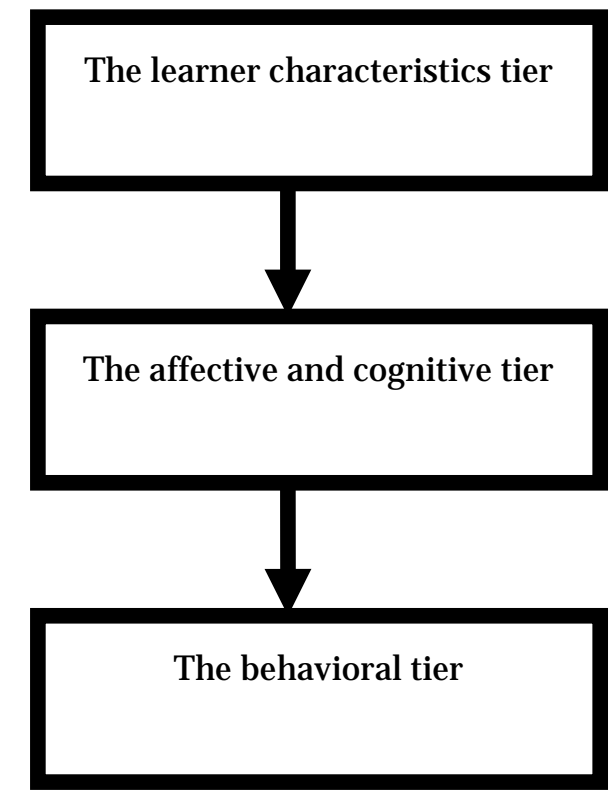


Figure 2: Investigating learner attitudes toward m-learning based on the three-tier research model

Based on the approach of social cognitive theory and three-tire research approach, we propose our research model (as shown in Figure 3).

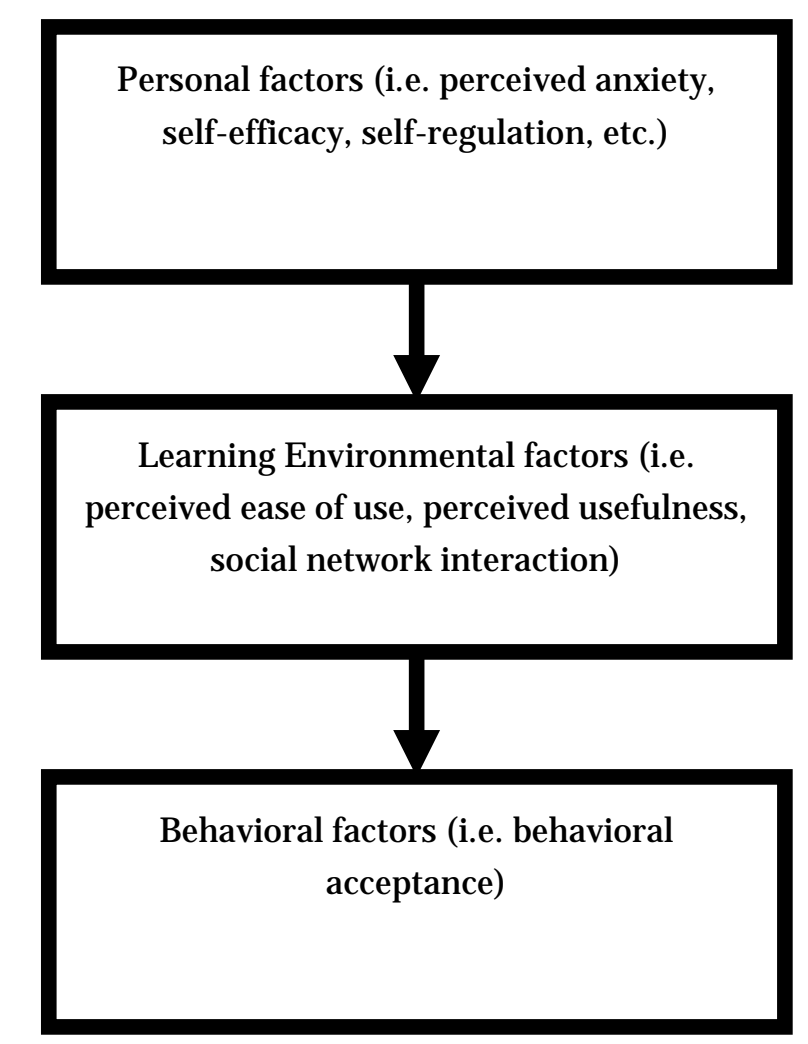

Figure 3: The research model

\section{Research Hypotheses}

Investigating user attitudes toward $\mathrm{m}$-learning is a crucial issue for improving $\mathrm{m}$-learning effects. The measurement of m-learning must incorporate different aspects of learners' perceptions to build a useful diagnostic instrument. It means investigating learner attitudes toward m-learning could facilitate the creation of appropriate m-learning environments for teaching and learning. But evaluating methods of m-learning measurement cannot be performed using a single linear methodology; therefore, collecting data on learner attitudes toward m-learning requires a multidisciplinary approach (Liaw, 2002, 2008). Liaw et al. (2010) also stated that when investigating learner behavioral acceptance toward m-learning, we need to identify the key 
predictors such as perceived self-efficacy, anxiety, self-regulation, learning interactive activities, and system quality (such as ease of use and usefulness).

Furthermore, progressively understanding gender difference toward m-learning is the major research objective of this study. As stated before, the previous studies (Albert \& J ohnson, 2011; Chu, 2010; Liaw, 2002; Liaw, 2007; Ong \& Lai, 2006) are not conclusive with respect to the level of positive attitudes toward information technology and gender. Therefore, based on our research model as shown in Figure 3, we will propose our research hypotheses based on personal factors (such as perceived self-efficacy, anxiety, and self-regulation) will affect learning environmental factors (such as perceived ease of use, perceived usefulness, social network interaction); additionally, learning environmental factors will positively influence behavioral factor (such as behavioral acceptance).

Regarding self-efficacy, Bandura (1997) asserted: "perceived self-efficacy refers to beliefs in one's capabilities to organize and execute the courses of action required to produce given attainments" (p.3). It is concerned not with the number of skills learners have but with what learners believe they can do with what they have under a variety of circumstances or situation (Bandura, 1997; Rogers, Conner \& Murray, 2008). Previous research found perceived self-efficacy to be positively predicted with achievement-related behaviors such as motivation, effectiveness, or positive attitudes (Bandura, 1986; Liaw, 2008). In m-learning environments, a high degree of perceived self-efficacy leads to improved behavioral retention (Liaw, 2008). Previous research had shown that improved perceived self-efficacy was highly correlated with perceived usefulness of using learning technologies and male learners had more positive attitudes to communicate with other learners on technology-based learning environments (Chu \& Chu, 2010; Liaw, 2008). Previous research found that learners' self-efficacy influences their attitudes and ability to acquire skills, choice of activities, and willingness to continue in a course of action when learning in m-learning environments. Therefore, we present the following hypotheses:

H1: Perceived self-efficacy is a positive predictor on perceived usefulness for both female and male university students.

H2: Perceived self-efficacy is a positive predictor on social network interaction for both female and male university students.

H3: Perceived self-efficacy is a positive predictor on perceived ease of use for both female and male university students.

Perceived anxiety refers to an unpleasant emotional state or condition characterized by apprehension or worry; specifically an emotional fear of potential negative outcomes (Spielberger, Gorsuch, \& Lushene, 1970). When individuals have the negative feelings associated with high levels of anxiety, they usually divert cognitive resources from job or task performance. Previous studies had explored the relationship between computer anxiety and Internet use, and found that 
computer anxiety was negatively related to students' use of the Internet (Barbeite \& Weiss, 2004; Durndell \& Haag, 2002; Kanfer \& Heggestad, 1999). Moreover, previous research also found that perceived anxiety had negative relationship with learner motivation, and self-regulation in technology-based learning environments (Tsai, 2009). Besides, perceived anxiety is a negative predictor on perceived satisfaction (Sun, Tsai, Finger, Chen, \& Yeh, 2008) and on perceived usefulness either (Sun et al., 2008; Tsai, 2009). Thus, we present the following hypotheses:

H4: Perceived anxiety is a negative predictor on perceived usefulness for both female and male university students.

H5: Perceived anxiety is a negative predictor on social network interaction for both female and male university students.

H6: Perceived anxiety is a negative predictor on perceived ease of use for both female and male university students.

Pintrich (2000) defined self-regulated learning as "an active, constructive process whereby learners set goals for their learning and then attempt to monitor, regulate, and control their cognition, motivation, and behavior, guided and constrained by their goals and the contextual features of the environment" (p. 453). Indeed, m-learning environments provide students with dynamic, interactive, nonlinear access to a wide range of information, as well as to self-directed learning (Kramarski \& Gutman, 2006). And the environments also provide flexible interactive functions to enhance social communication; thus m-learning potentially creates a powerful selfregulated learning environment (Tsai, 2009). Kramarski and Gutman (2006) stated that selfregulated learners are more active participants in the learning process and have more behavioral motivation in their own learning objectives. Tsai (2009) observed that perceived self-regulation is highly correlated with learners' perceived usefulness in learning environments. Furthermore, both Kramarski and Gutman (2006) and Roca and Gagne (2008) found a high degree of correlation between perceived self-regulation and high system quality, such as ease of use and friendly interactive functions. Therefore, we present the following hypotheses:

H7: Perceived self-regulation is a positive predictor on perceived usefulness for both female and male university students.

H8: Perceived self-regulation is a positive predictor on social network interaction for both female and male university students.

H9: Perceived self-regulation is a positive predictor on perceived ease of use for both female and male university students.

TAM (Technology Acceptance Model) is a popular research approach for surveying user attitudes toward information technologies (Davis, Bagozzi, \& Warsaw, 1989; Venkatesh \& Davis, 2000). 
The concept of TAM suggested that two specific behavioral beliefs, perceived ease of use (EOU), and perceived usefulness (U), determined an individual's behavioral intention to use technologies. Sun, et al. (2008) and Cheung and Vogel (2013) found that perceived ease of use was a key predictor in affecting learners' behavioral intention to use technology and positively impacted perceived usefulness. They also provided evidence that perceived ease of use is a crucial factor on system's satisfaction. Therefore, we present the following hypotheses:

H10: Perceived ease of use is a positive predictor on perceived usefulness for both female and male university students.

H11: Perceived ease of use is a positive predictor on social network interaction for both female and male university students.

H12: Perceived ease of use is a positive predictor on behavioral acceptance for both female and male university students.

From the research of Liaw and Huang (2014), they stated that perceived usefulness had high correlation with interactive environments in mobile learning environments. They also argued that perceived usefulness was a key factor to predict behavioral intention; this evidence supports TAM concept. Therefore, we present the following hypotheses:

H13: Perceived usefulness is a positive predictor on social network interaction for both female and male university students.

H14: Perceived usefulness is a positive predictor on behavioral acceptance for both female and male university students.

H15: Social network interaction is a positive predictor on behavioral acceptance for both female and male university students.

Based on the research hypotheses, we propose a conceptual research model shown in Figure 4. 


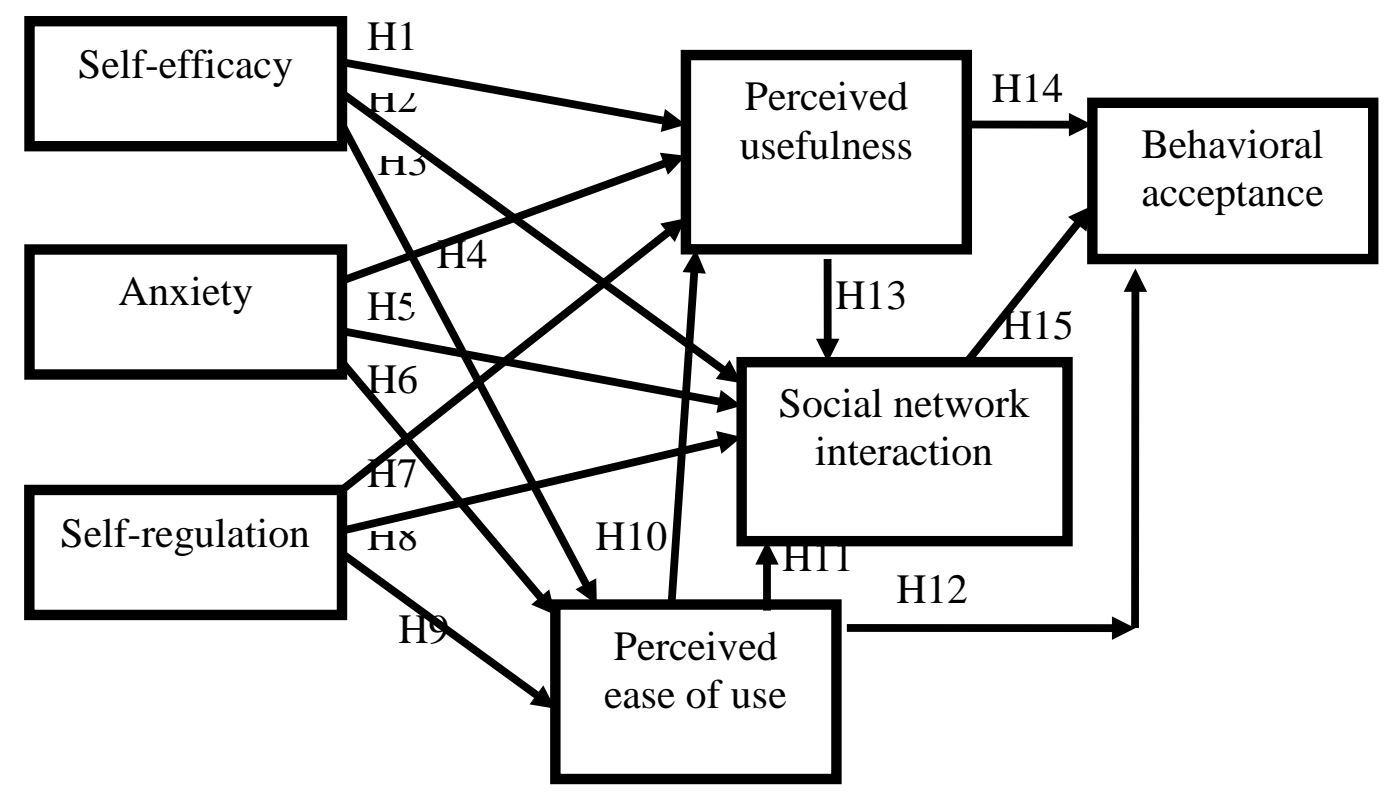

Figure 4: The conceptual research model based on research hypotheses

\section{System Development}

This research designs an APP-based system as an assisted m-learning environment. The APPbased m-learning system can be operated at personal computers or mobile devices for distance learning. Students plug into and use the system on their smart phones. The major functions in the m-learning system include various applications that Liaw et al. (2010) suggested: educational content delivery function, adaptive learning function, interactive and sharing functions, system brochure, and email to instructor. The educational content delivery function refers to creating learning platforms on mobile devices; the adaptive learning function of learning environments mandates building content development tools that support delivery of learning content on mobile devices; and the interactive and collaborative function focuses on creating mobile interaction among students and/or teachers for social communication. We integrated our system with the Facebook (http://www.facebook.com); therefore, users can use the "LIKE" function of the Facebook when they like other learners' posted resources or posted opinions.

\section{Methodology}

Regarding the research methodology, we present participants first and then introduce the research measurement. In this research, 159 university students answer questionnaire surveys after using an APP-based m-learning system for one month. 


\section{Participants}

To progressively understand learners' attitudes toward the APP-based m-learning system, the questionnaire collected demographic information and posed questions related to experience using computers and Internet; besides, attitudes toward the APP-based m-learning system also were included in this questionnaire. The paper-based questionnaires were distributed with a cover letter. A total of 159 valid responses were collected in a middle Taiwan's university; 77 participants were female learners and 82 participants were male students. Fourteen students were 18-years-old, 105 students were 19-20-years-old, 21 students were 21-22-year-olds, 5 students were 23-24-years-old, and 14 students were over 25-years-old.

\section{Measurement}

The questionnaire covers seven factors. The five factors of perceived self-efficacy, perceived anxiety, perceived usefulness, social network interaction, and behavioral acceptance were revised from Liaw et al. (2010) ( $\alpha=0.96)$. Questionnaire items for self-regulation were revised from Liaw and Huang (2014) ( $\alpha=0.95)$. Questionnaire items for perceived ease of use were revised from Sun et al., (2008) ( $\alpha=0.90$ ). Based on these studies, questionnaire items were designed to focus on investigating learners' attitudes toward learning systems. The seven-factor questionnaire covered 30 items, each item using a seven-point Likert scale $(1=$ "strongly disagree" to $7=$ "strongly agree") (shown in the appendix).

\section{Results}

\section{Descriptive Statistical Analyses}

The descriptive statistical results are presented in Table 1 and Table 2. Table 1 presents demographic information of female and male students' experience of computers, smart phones, and the Internet. In the seven-point Likert item questionnaire, from Table 2, descriptive statistical results showed that female students and male students both had high positive attitudes toward m-learning use in factors of perceived self-efficacy, self-regulation, ease of use, usefulness, social network interaction, and behavioral acceptance. Although female learners had slightly higher mean values than male learners for six of these factors, there was no significant gender differences indicated by the t-test. Regarding the perceived anxiety, male learners had slightly higher mean value than female learners; however, there still was no significant gender difference.

Table 1

This work is licensed under a Creative Commons Attribution 4.0 International License. 
Students' Computers, Smart Phones, and the Internet Experience

\begin{tabular}{|l|l|l|l|l|l|l|}
\hline & \multicolumn{2}{|l|}{$\begin{array}{l}\text { Using Computers } \\
\text { Per Week }\end{array}$} & \multicolumn{2}{l|}{$\begin{array}{l}\text { Using Smart } \\
\text { Phones Per Week }\end{array}$} & \multicolumn{2}{l|}{$\begin{array}{l}\text { Using Internet } \\
\text { Per Week }\end{array}$} \\
\hline & Female & Male & Female & Male & Female & Male \\
\hline Less than 1 hour & 0 & 1 & 2 & 4 & 0 & 0 \\
\hline $1-5$ hours & 11 & 10 & 10 & 12 & 2 & 0 \\
\hline $6-10$ hours & 9 & 11 & 17 & 15 & 14 & 4 \\
\hline $11-15$ hours & 17 & 7 & 15 & 13 & 13 & 11 \\
\hline $16-20$ hours & 7 & 8 & 9 & 9 & 7 & 8 \\
\hline Over 21 hours & 33 & 45 & 24 & 29 & 41 & 59 \\
\hline
\end{tabular}

Table 2

Mean Values

\begin{tabular}{|l|l|l|l|l|}
\hline Constructs & $\begin{array}{l}\text { Mean } \\
\text { (Female } \\
\text { ) }\end{array}$ & $\begin{array}{l}\text { Mean } \\
\text { (Male) }\end{array}$ & $\begin{array}{l}\text { T-Test } \\
\text { Significance }\end{array}$ & p \\
\hline Perceived Self-Efficacy & 5.45 & 5.28 & No & 0.26 \\
\hline Perceived Anxiety & 2.91 & 3.01 & No & 0.66 \\
\hline Perceived Self-Regulation & 5.40 & 5.28 & No & 0.16 \\
\hline Perceived Ease of Use & 5.67 & 5.51 & No & 0.29 \\
\hline Perceived Usefulness & 5.60 & 5.37 & No & 0.10 \\
\hline Social Network Interactive & 5.32 & 5.08 & No & 0.25 \\
\hline Behavioral Acceptance & 5.29 & 5.16 & No & 0.09 \\
\hline
\end{tabular}




\section{Reliability Analyses}

Reliability analyses were the procedure used to ascertain the internal consistency of the measures. According to Hair, Black, Babin, and Anderson (2009), Cronbach's alpha above 0.6 for exploratory study is considered reliable. In this research, Cronbach's alpha of female students is 0.942 and all constructs of the range of Cronbach's alpha are between 0.905 and 0.970 . Cronbach's alpha of male students is 0.940 and all constructs of the range of Cronbach's alpha are between 0.875 and 0.953 . Thus all measures in the study are reliable. Table 3 presented the results of Cronbach's alpha.

Table 3

Cronbach's Alpha of Female and Male Students

\begin{tabular}{|l|l|l|}
\hline Constructs & $\begin{array}{l}\text { Cronbach's } \\
\text { Alpha (Female) }\end{array}$ & $\begin{array}{l}\text { Cronbach's } \\
\text { Alpha (Male) }\end{array}$ \\
\hline & .942 & .940 \\
\hline Perceived Self-Efficacy & .918 & .928 \\
\hline Perceived Anxiety & .957 & .953 \\
\hline Perceived Self-Regulation & .944 & .875 \\
\hline Perceived Ease Of Use & .970 & .928 \\
\hline Perceived Usefulness & .957 & .914 \\
\hline Social Network Interactive & .905 & .944 \\
\hline Behavioral Acceptance & .937 & .929 \\
\hline
\end{tabular}

\section{Relationships between Factors}

The research model is based on partial least square (PLS). PLS technique was applied to detect relationships among constructs. Therefore, we apply PLS to find relationship among seven factors. Kline (2005) states convergent validity is achieved if loadings of the measures to their respective constructs should be at least 0.60 . Table 4 shows the range of male students' loadings are from 0.741 to 0.972 ; and the range of female students' loadings are from 0.866 to 0.982 . Therefore, convergent validity is established. Regarding to the composite reliability (CR) and variance extracted (AVE), CR of all constructs was above 0.6 and AVE was above 0.5; thus further supporting convergent validity (Bagozzi \& Yi, 1988; Fornell \& Larcker, 1981). According to 
discriminant validity, the inter-variable correlations (Table 5 and Table 6) were examined and the square root AVE were higher than correlations suggesting that the construct was more closely related to its own measures; therefore, supporting discriminant validity (Fornell \& Larcker, 1981).

Table 4

The Loading, CR, and AVE

\begin{tabular}{|c|c|c|c|c|c|c|c|}
\hline \multirow[t]{2}{*}{ Construct } & \multirow[t]{2}{*}{ Item } & \multicolumn{3}{|l|}{ Female } & \multicolumn{3}{|l|}{ Male } \\
\hline & & Loading & CR & AVE & Loading & CR & AVE \\
\hline \multirow{2}{*}{$\begin{array}{l}\text { Perceived } \\
\text { Self- }\end{array}$} & Effi01 & 0.917 & \multirow[t]{3}{*}{0.948} & \multirow[t]{3}{*}{0.858} & 0.943 & \multirow[t]{3}{*}{0.954} & \multirow[t]{3}{*}{0.874} \\
\hline & Effi02 & 0.947 & & & 0.951 & & \\
\hline Efficacy & Effi03 & 0.916 & & & 0.910 & & \\
\hline \multirow{3}{*}{$\begin{array}{l}\text { Perceived } \\
\text { Anxiety }\end{array}$} & Anxi01 & 0.956 & \multirow[t]{3}{*}{0.973} & \multirow[t]{3}{*}{0.922} & 0.946 & \multirow[t]{3}{*}{0.969} & \multirow[t]{3}{*}{0.913} \\
\hline & Axni02 & 0.982 & & & 0.954 & & \\
\hline & Anxi03 & 0.956 & & & 0.964 & & \\
\hline \multirow{6}{*}{$\begin{array}{l}\text { Perceived } \\
\text { Self- } \\
\text { Regulation }\end{array}$} & Regu01 & 0.899 & \multirow[t]{6}{*}{0.959} & \multirow[t]{6}{*}{0.796} & 0.741 & \multirow[t]{6}{*}{0.905} & \multirow[t]{6}{*}{0.614} \\
\hline & Regu02 & 0.886 & & & 0.795 & & \\
\hline & Regu03 & 0.928 & & & 0.777 & & \\
\hline & Regu04 & 0.915 & & & 0.775 & & \\
\hline & Regu05 & 0.886 & & & 0.773 & & \\
\hline & Regu06 & 0.837 & & & 0.837 & & \\
\hline \multirow{3}{*}{$\begin{array}{l}\text { Perceived } \\
\text { Ease Of } \\
\text { Use }\end{array}$} & Ease01 & 0.968 & \multirow[t]{3}{*}{0.981} & \multirow[t]{3}{*}{0.945} & 0.930 & \multirow[t]{3}{*}{0.954} & \multirow[t]{3}{*}{0.874} \\
\hline & Ease02 & 0.980 & & & 0.941 & & \\
\hline & Ease03 & 0.967 & & & 0.933 & & \\
\hline Perceived & Use01 & 0.866 & 0.961 & 0.804 & 0.868 & 0.934 & 0.704 \\
\hline
\end{tabular}

This work is licensed under a Creative Commons Attribution 4.0 International License. 


\begin{tabular}{|c|c|c|c|c|c|c|c|}
\hline \multirow[t]{5}{*}{ Usefulness } & Use02 & 0.893 & & & 0.870 & & \\
\hline & Use03 & 0.898 & & & 0.823 & & \\
\hline & Use04 & 0.911 & & & 0.789 & & \\
\hline & Use05 & 0.913 & & & 0.842 & & \\
\hline & Use06 & 0.898 & & & 0.840 & & \\
\hline \multirow{3}{*}{$\begin{array}{l}\text { Social } \\
\text { Network } \\
\text { Interaction }\end{array}$} & Soci01 & 0.956 & \multirow[t]{3}{*}{0.976} & \multirow[t]{3}{*}{0.931} & 0.938 & \multirow[t]{3}{*}{0.965} & \multirow[t]{3}{*}{0.902} \\
\hline & Soci02 & 0.982 & & & 0.972 & & \\
\hline & Soci03 & 0.956 & & & 0.939 & & \\
\hline \multirow{6}{*}{$\begin{array}{l}\text { Behavioral } \\
\text { Acceptance }\end{array}$} & Acce01 & 0.868 & \multirow[t]{6}{*}{0.966} & \multirow[t]{6}{*}{0.827} & 0.859 & \multirow[t]{6}{*}{0.945} & \multirow[t]{6}{*}{0.740} \\
\hline & Acce02 & 0.895 & & & 0.801 & & \\
\hline & Acce03 & 0.930 & & & 0.906 & & \\
\hline & Acce04 & 0.938 & & & 0.898 & & \\
\hline & Acce05 & 0.920 & & & 0.827 & & \\
\hline & Acce06 & 0.905 & & & 0.865 & & \\
\hline
\end{tabular}

Table 5

The Inter-Variable Correlations of Female Students

\begin{tabular}{|l|l|l|l|l|l|l|l|}
\hline & BA & EU & SNI & ANX & SE & SR & USE \\
\hline BA & 0.909 & & & & & & \\
\hline EU & 0.659 & 0.972 & & & & & \\
\hline SNI & 0.666 & 0.425 & 0.965 & & & & \\
\hline ANX & 0.108 & -0.227 & 0.203 & 0.950 & & & \\
\hline
\end{tabular}

This work is licensed under a Creative Commons Attribution 4.0 International License. 


\begin{tabular}{|l|l|l|l|l|l|l|l|}
\hline SE & 0.542 & 0.610 & 0.323 & -0.163 & 0.925 & & \\
\hline SR & 0.710 & 0.691 & 0.528 & 0.041 & 0.463 & 0.783 & \\
\hline USE & 0.760 & 0.765 & 0.603 & -0.068 & 0.468 & 0.625 & 0.986 \\
\hline
\end{tabular}

Table 6

The Inter-Variable Correlations of Male Students

\begin{tabular}{|l|l|l|l|l|l|l|l|}
\hline & BA & EU & SNI & ANX & SE & SR & USE \\
\hline BA & 0.861 & & & & & & \\
\hline EU & 0.524 & 0.935 & & & & & \\
\hline SNI & 0.668 & 0.460 & 0.950 & & & & \\
\hline ANX & 0.109 & -0.114 & 0.088 & 0.961 & & & \\
\hline SE & 0.432 & 0.512 & 0.158 & -0.163 & 0.935 & & \\
\hline SR & 0.639 & 0.583 & 0.498 & 0.041 & 0.524 & 0.892 & \\
\hline USE & 0.738 & 0.676 & 0.581 & -0.068 & 0.607 & 0.823 & 0.839 \\
\hline
\end{tabular}

\section{Hypotheses Investigation}

In this research, PLS technique was applied to detect relationships among seven factors (perceived self-efficacy, perceived anxiety, perceived self-regulation, perceived ease of use, perceived usefulness, social network interaction, and behavioral acceptance). After PLS analyses, Table 7 shows the results of 15 hypotheses (including female and male learners). Based on the results for female learners, five hypotheses were not supported, specifically:H2, H4, H5, H8, and H11. H5 was not supported because of positive prediction. This result indicated that female learners with higher anxiety toward m-learning were more willing to socially interact with other learners. For the male learners, three hypotheses were not supported including H4, H5 and H12. According to the statistical results, female and male students still have gender difference toward m-learning. The hypothesis 4 was not supported because of positive prediction. This result indicates that learners reporting a higher level of anxiety toward m-learning feel more positively towards m-learning being a useful learning tool. 
Table 7

The Results of 15 Hypotheses (Including Female and Male Students)

\begin{tabular}{|c|c|c|c|c|c|c|c|}
\hline \multicolumn{2}{|c|}{ Hypothesis } & \multicolumn{3}{|c|}{ Female Students } & \multicolumn{3}{|c|}{ Male Students } \\
\hline & Prediction & $\beta$ & $\mathrm{p}$ & true & $\beta$ & $\mathrm{p}$ & true \\
\hline $\mathrm{H} 1$ & Self-efficacy $\rightarrow$ usefulness & .135 & $<01$ & Yes & .104 & $<01$ & Yes \\
\hline $\mathrm{H} 2$ & Self-efficacy $\rightarrow$ social network & & $>.05$ & No & -.229 & $<01$ & Yes \\
\hline H3 & Self-efficacy $\rightarrow$ ease of use & .291 & $<01$ & Yes & .268 & $<01$ & Yes \\
\hline $\mathrm{H} 4$ & Anxiety $\rightarrow$ usefulness & & $>.05$ & No & .043 & $<05$ & No \\
\hline H5 & Anxiety $\rightarrow$ social network & .244 & $<01$ & No & & $>.05$ & No \\
\hline $\mathrm{H} 6$ & Anxiety $\rightarrow$ ease of use & -.202 & $<01$ & Yes & -.125 & $<01$ & Yes \\
\hline H7 & Self-regulation $\rightarrow$ usefulness & .536 & $<01$ & Yes & .311 & $<01$ & Yes \\
\hline H8 & Self-regulation $\rightarrow$ social network & & $>.05$ & No & .245 & $<01$ & Yes \\
\hline H9 & Self-regulation $\rightarrow$ ease of use & .546 & $<01$ & Yes & .476 & $<01$ & Yes \\
\hline H10 & Ease of use $\rightarrow$ usefulness & .313 & $<01$ & Yes & .446 & $<01$ & Yes \\
\hline H11 & Ease of use $\rightarrow$ social network & & $>.05$ & No & .138 & $<01$ & Yes \\
\hline H12 & Ease of use $\rightarrow$ acceptance & .216 & $<01$ & Yes & & $>.05$ & No \\
\hline $\mathrm{H} 13$ & Usefulness $\rightarrow$ social network & .604 & $<01$ & Yes & .441 & $<01$ & Yes \\
\hline H14 & Usefulness $\rightarrow$ acceptance & .391 & $<01$ & Yes & .527 & $<01$ & Yes \\
\hline H15 & Social network $\rightarrow$ acceptance & .338 & $<01$ & Yes & .361 & $<01$ & Yes \\
\hline
\end{tabular}

\section{Discussions}

A better understanding of the gender perspectives toward m-learning can assist researchers and educators to realize how to take into consideration gender factors when developing $\mathrm{m}$-learning 
platforms for both female and male learners. Based on the results of Table 1, there is no significant gender difference of learner attitudes toward m-learning in seven factors. In other words, although female and male students both have highly positive attitudes toward m-learning environments; there is no significant gender difference. Unlike previous research of Albert and J ohnson (2011), as well as Padilla-Meléndez, Aguila-Obra, and Garrido-Moreno (2013), our findings provide evidence that both female and male learners have highly positive attitudes toward mlearning environments.

On the other hand, from the conceptual model in Figure 4, our statistical results overlaid on our conceptual model (as shown in Figure 5 and Figure 6). The results showed that self-efficacy and self-regulation were better predictive factors for male learners while perceived anxiety was a more contributive factor for female students, especially predicting social network interaction. This means that when social network functions are integrated into m-learning systems, perceived anxiety is a significant predictor for female learning, while, perceived self-efficacy and selfregulation are significant contributors for male learners. Although ease of use is a significant predictor for perceived usefulness, it is not a contributor for male learner behavioral acceptance. Furthermore, for female learners, perceived anxiety is a positive predictor on social network interaction but is a negative predictor on perceived ease of use. For male learners, perceived selfefficacy is a negative predictor on social network interaction, and perceived anxiety can positively predict perceived usefulness, as well as, negatively predict perceived ease of use. From these statistical results, it can be inferred that this is evidence of gender difference toward m-learning which was not detected from previous studies (Albert \& Johnson, 2011; Chu, 2010; GonzálezGómez, Guardiola, Rodríguez \&Alonso, 2012; Ong \& Lai, 2006; Padilla-Meléndez et al., 2013). 


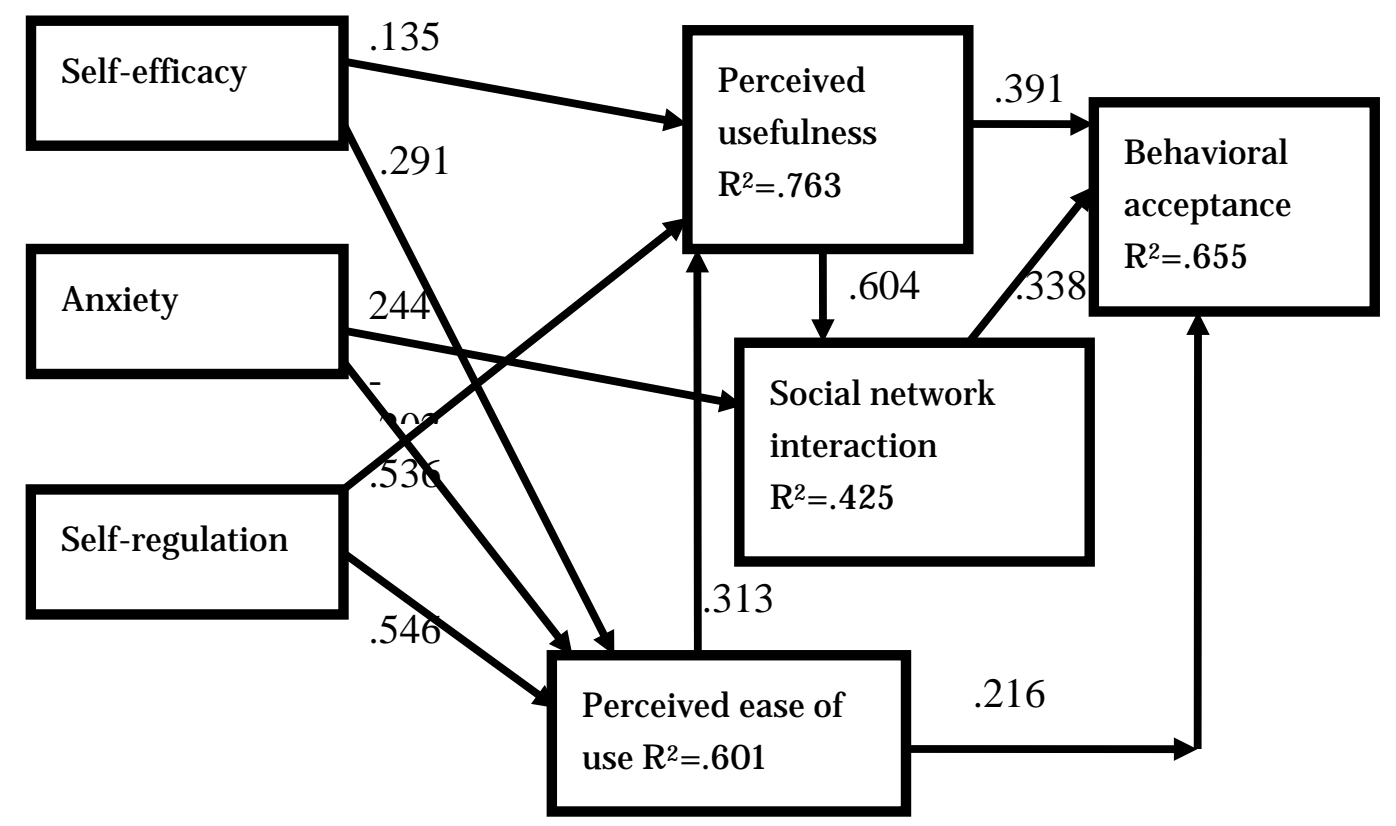

Figure 5: Female Students' Research Model

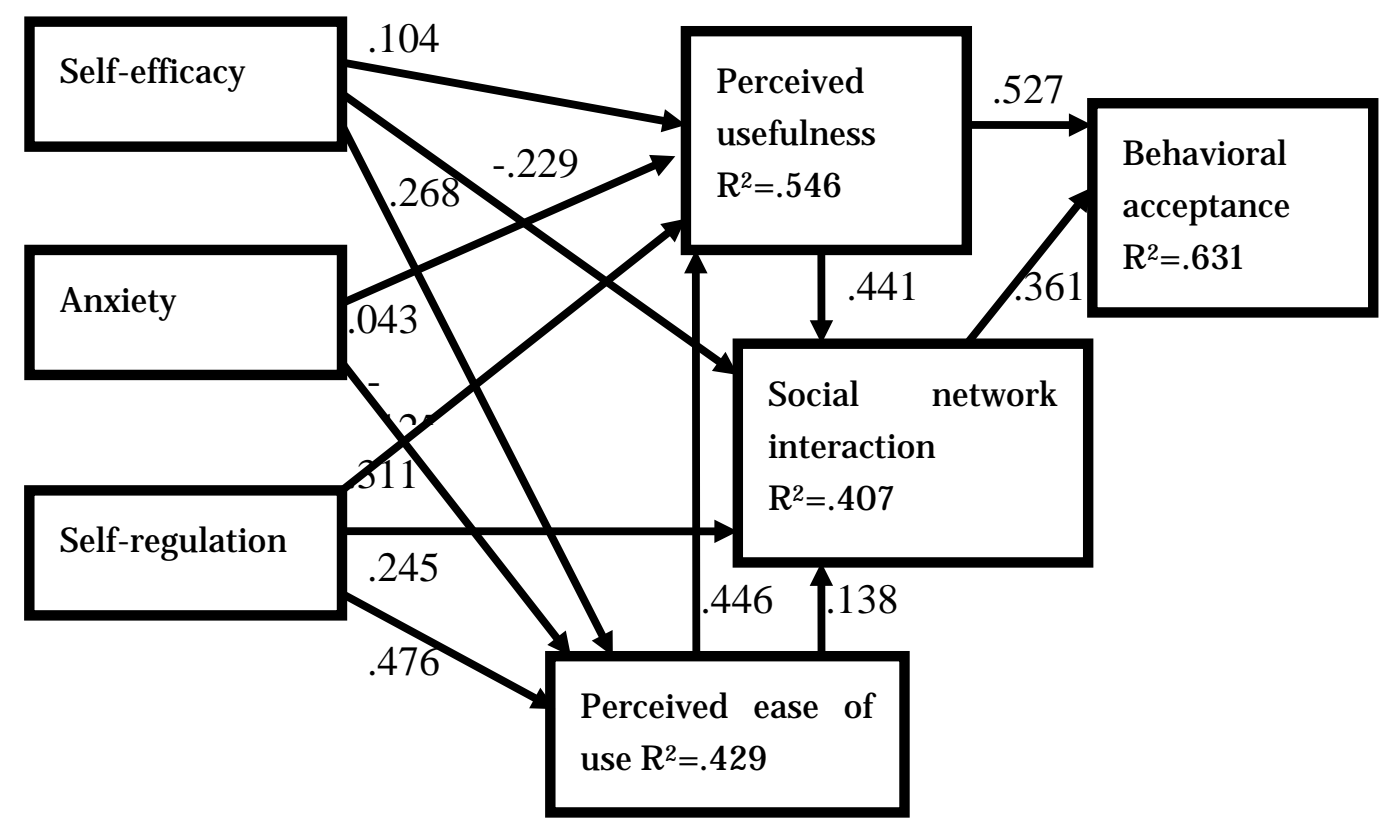

Figure 6: Male Students' Research Model

Indeed, based on the research model in Figure 3, we realize personal factors (i.e. anxiety, selfefficacy, and self-regulation) are significant contributors for environmental factors (i.e. ease of use, usefulness, and social network interaction). However, we found that gender difference occurs 
here because perceived self-efficacy and self-regulation contributed more for male learners while perceived anxiety was a better predictor for female learners. Furthermore, environmental factors, such as perceived ease of use, usefulness, and social network interaction, were significant predictors for learners' behavioral acceptance toward m-learning environments, but perceived ease of use is not a predictor on male learners. It seems that male students are more comfortable with using m-learning systems than female students.

\section{Conclusions}

In this research, we proposed a seven-factor conceptual model for investigating the gender differences of attitudes towards the m-learning system. The factors include perceived self-efficacy, anxiety, self-regulation, ease of use, usefulness, social network interaction, and behavioral acceptance. We have designed an APP-based m-learning system that was used by undergraduate students in the context of three courses. After the period of one month, we collected questionnaires examining students' attitudes and performed the analysis. The results lead to following conclusions:

\subsection{The SCT is an acceptable theory to understand attitudes toward m-learning.}

The research is to investigate learner attitudes toward m-learning based on SCT. Indeed, the study focuses on the predictive relationships among personal factors, environment factors, and behavioral factor. After statistical analyses, we found that personal factors (such as perceived selfefficacy, anxiety, and self-regulation) were predictors on learning environment factors (such as perceived usefulness, ease of use, and social network interaction), as well as learning environment factors were positive predictors on behavioral acceptance. On other words, the SCT is acceptable theoretical concept to understand learners' attitudes, both female and male learners, toward mlearning.

8.2. The proposed model is an acceptable conceptual model for investigating female and male learners' attitudes.

The proposed research conceptual model of Figure 4 is an adaptive conceptual model to survey learners' (including female and male learners) attitudes toward m-learning. In Figure 3 and Figure 4, learners' personal factors could predict learning environmental factors. At the same time, learning environmental factors could also predict behavioral factors. Therefore, our research results support previous research of Liaw(2008) and Liaw and Huang (2014).

\subsection{Gender difference is an issue in attitudes toward m-learning acceptance.}

After investigating our 15 hypotheses as presented in Figure 4, we may conclude that gender influences attitudes towards m-learning acceptance. Perceived anxiety is a positive significant predictor for social network interaction for female learners while perceived self-efficacy and perceived self-regulation have more positive contribution for male learners. Perceived usefulness 
has the highest contribution on behavioral acceptance toward m-learning for both female and male learners. These results are aligned with previous studies (Carr, 2005; Okazaki \& Renda dos Santos, 2012; Ong \& Lai, 2006) claiming that female and male learners have different cause relationship among attitudes toward m-learning.

\subsection{Social network interaction is a significant factor to enhance behavioral acceptance.}

Social network interaction is a significant predictor on behavioral acceptance toward m-learning for both female and male learners. This statistical evidence supports that social interaction-based $\mathrm{m}$-learning systems are adaptive mobile learning platforms for both female and male learners. The result could support social network interaction as a key success factor to enhance learners' acceptance toward m-learning.

\subsection{Both female and male learners have highly positive attitudes toward m-learning.}

Both female and male learners have highly positive perceptions toward applying APP-based mlearning systems for learning purposes. While some previous studies (Chu, 2010; Ong \& Lai, 2006) found higher positive attitudes toward educational technology for male students, other studies (Albert \&J ohnson, 2011; González-Gómez et al., 2012) found that female learners prefer applying educational technology to assist their learning activities more. This research shows that female and male learners have both highly positive perceptions toward applying APP-based mlearning environments.

\subsection{Perceived anxiety is a significant predictor for female learners.}

Based on the statistical results, perceived anxiety is the most significantly positive predictor on social network interaction for female learners. These results can be explained when female learners have higher perceived anxiety toward m-learning; then they also have higher intention to share their learning experience and ideas. On the other hand, perceived anxiety is a positive predictor of perceived usefulness for male learners. These results indicate that for male learners', perceived anxiety toward m-learning increases their positive feelings toward m-learning as a useful learning tool. Therefore, the results show that for both female and male learners, perceived anxiety is a negative predictor on perceived ease of use.

8.7. Perceived self-efficacy is a negative predictor on social network interaction for male students.

The statistical results show that perceived self-efficacy is a negative predictor on social network interaction for male students, but perceived self-efficacy is not a predictor on social network interaction for female learners at the same time. The information indicates when male learners have more self-efficacy using APP-based m-learning, then they have less interest in social interaction with other learners. 


\subsection{Perceived self-regulation has gender difference.}

The statistical results provide evidence that perceived self-regulation has gender difference. Based on the Table 7, perceived self-regulation of female students is a significant predictor on perceived ease of use and perceived usefulness; on the other hand, it has more positive influence on social network interaction for male university learners.

In the future research, when investigating gender difference toward educational technology, especially APP-based mobile technology, we are not only to focus on students' attitudes toward APP-based m-learning, but also to do more efforts to figure out causal relationships among factors of learners' attitudes. Indeed, based on the social cognitive theory approach, future research could investigate progressively more gender difference on relationship and prediction among personal attitude factors and learning environmental factors to understand better about learner behavioral acceptance toward mobile technology.

\section{Acknowledgements}

We would like to thank the reviewers of the IRRODL journal for their thoughtful and helpful comments. We also appreciate Professor Marek Hatala's comments. The research was partially supported by the national projects MOST101-2511-S-039-004-MY2 and MOST104-2511-S-039001-MY2. 


\section{References}

Albert, L. J ., \&J ohnson, C. S. (2011). Socioeconomic status- and gender-based differences in students' perceptions of e-learning systems. Decision Sciences J ournal of Innovative Education, 9(3), 421-436.

Bagozzi, R. P., \&Yi, Y. (1988). On the evaluation of structural equation models. J ournal of the Academy of Marketing Science, 16 , pp. 74-94.

Bandura, A. (1986). Social foundations of thought and action: A social cognitive theory. Englewood Cliffs, NJ , Prentice Hall.

Bandura, A. (1997). Self-efficacy: The exercise of control. New York: Freeman.

Carr, D. (2005). Contexts, gaming pleasures, and gendered preferences. Simulation \& Gaming, 36(4), 464-482.

Cheung, R., \&Vogel, D. (2013). Predicting user acceptance of collaborative technologies: An extension of the technology acceptance model for e-learning. Computer \& Education, 63, 160-175.

Chu, R. J . C. (2010). How family support and internet self-efficacy influence the effects of elearning among higher aged adults - Analyses of gender and age differences. Computers \&Education, 55, 255-264.

Chu, R. J ., \& Chu, A. Z. (2010). Multi-level analysis of peer support, internet self-efficacy and elearning outcomes - The contextual effects of collectivism and group potency. Computers \&Education, 55(1), 145- 154.

Crescente, M. L., and Lee, D. (2011). Critical issues of m-learning: design models, adoption processes, and future trends. J ournal of the Chinese Institute of Industrial Engineers, 28(2), 111- 123.

Crompton, H. (2013). "A historical overview of mobile learning: Toward learner-centered education.” In Z. L. Berge \& L. Y. Muilenburg (Eds.), Handbook of mobile learning (pp. 3-14). Florence, KY: Routledge.

Davis, F. D., Bagozzi, R. P., \&Warsaw, P. R. (1989). User acceptance of computer technology: A comparison of two theoretical models. Management Science, 35(8), 983- 1003.

Fornell, C. R., \& Larcker, D. F. (1981). Evaluating structural equation models with unobserved variables and measurement error. J ournal of Marketing Research, XVIII, pp. 39-50. 
González-Gómez , F., Guardiola, J ., Rodríguez, O. M., \&Alonso, M. A. M. (2012). Gender differences in e-learning satisfaction. Computers \&Education, 58, 283-290.

Hair, J . F., Black, W. C., Babin, B. J ., \&Anderson, R. E. (2009). Multivariate data analysis, $\mathrm{NJ}$ :Prentice Hall.

J ung, I. S. (2012). Asian learners' perception of quality in distance education and gender differences. International Review of Research in Open and Distance Learning, 13(2), 124.

Kline, K. B. (2005). Principles and Practice of Structural Equation Modeling. NY:Guilford Press.

Kramarski, B., \& Gutman, M. (2006). How can self-regulated learning be supported in mathematical e-learning environments? J ournal of Computer Assisted Learning, 22, 2433.

Liaw, S. S. (2007). Investigating sex differences and learners' autonomy toward e-learning: based on UK and Taiwan surveys, Psychological Reports, 100, 949-954.

Liaw, S. S. (2008). Investigating students' perceived satisfaction, behavioral intention, and effectiveness of e-learning: A case study of the Blackboard system. Computers \& Education, 51(2), 864-873.

Liaw, S. S., Hatala, M., \& Huang, H. M. (2010). Investigating acceptance toward mobile learning to assist individual knowledge management: based on activity theory approach. Computers \&Education, 54(2), 446- 454.

Liaw, S. S., \& Huang, H. M. (2014). Investigating learner attitudes toward e-books as learning tools: Based on the activity theory approach, Interactive Learning Environments.

Lin , C. P. (2010). Learning Virtual Community Loyalty Behavior From a Perspective of Social Cognitive Theory. International J ournal of Human-Computer Interaction, 26(4), 345360.

McConatha, D., Praul, M., \& Lynch, M. J . (2008). Mobile learning in higher education: An empirical assessment of a new educational tool. The Turkish Online J ournal of Educational Technology, 7 (3), 15-21. 
Motiwalla, L. F. (2007). Mobile learning: A framework and evaluation. Computers \& Education, 49(3), 581-596.

Okazaki, S., \& Renda dos Santos, I. M. (2012). Understanding e-learning adoption in brazil: Major determinants and gender effects, International Review of Research in Open and Distance Learning, 13(4), 91-106.

Ong, C. S., \& Lai, J . Y. (2006). Gender differences in perceptions and relationships among dominants of e-learning acceptance. Computers in Human Behavior, 22, 816- 829.

Padilla-Meléndez, A., Aguila-Obra, A. R., and Garrido-Moreno, A. (2013). Perceived playfulness, gender differences and technology acceptance model in a blended learning scenario. Computers \&Education, 63, 306-317.

Pintrich, P. R. (2000). A motivational science perspective on the role of student motivation in learning and teaching contexts. J ournal of Educational Psychology, 95, 667- 686.

Roca, J . C., \& Gagne, M. (2008). Understanding e-learning continuance intention in the workplace: A self-determination theory perspective. Computers in Human Behavior, 24, 1585- 1604.

Rodgers, W. M., Conner, M., \& Murray, T. C. (2008). Distinguishing among perceived control, perceived difficulty, and self-efficacy as determinants of intentions and behaviours. British J ournal of Social Psychology, 47(4), 607-630.

Sun, P. C., Tsai, R. J ., Finger, G., Chen, Y. Y., \&Yeh, D. (2008). What drives a successful eLearning? An empirical investigation of the critical factors influencing learner satisfaction. Computers \& Education, 50, 1183-1202.

Tsai, M. J . (2009). The model of strategic e-learning: Understanding and evaluating student elearning from metacognitive perspective. Educational Technology \& Society, 12(1), 3448.

Venkatesh, V., \& Davis, F. D. (2000). A theoretical extension of the technology acceptance model: Four longitudinal field studies. Management Science, 26(2), 186-204.

Wan, Z., Wang, Y., \& Haggerty, N. (2008).Why people benefit from e-learning differently: The effects of psychological processes on e-learning outcomes. Information \& management, 45, 513-521.

Wang, S. L., \& Lin, S. S. J . (2007). The application of social cognitive theory to web-based learning through NetPorts. British J ournal of Educational Technology, 38(4), 600-612. 
Wu, J . H., Tennyson, R. D., \&Hsia, T. L. (2010). A study of student satisfaction in a blended elearning system environment. Computers \& Education, 55(1), 155- 164.

\section{Appendix}

\section{Questionnaire}

\begin{tabular}{|l|l|l|}
\hline Factor & $\begin{array}{l}\text { Questionnaire } \\
\text { Item }\end{array}$ & Questionnaire Content \\
\hline $\begin{array}{l}\text { Perceived Self- } \\
\text { Efficacy }\end{array}$ & Effi01 & I feel confident using the APP. \\
\hline & Effi02 & I feel confident using resources of the APP. \\
\hline $\begin{array}{l}\text { Perceived } \\
\text { Anxiety }\end{array}$ & Effi03 & I feel confident operating APP functions. \\
\hline & Anxi01 & I feel it is difficult using the APP. \\
\hline Rerceived Self- & Anxi02 & I feel nervous using the APP. \\
\hline & Regulation & I feel using the APP is complicated. \\
\hline & The & The APP is a self-regulated learning tool. \\
\hline & The APP is an active learning tool. \\
\hline & Regu04 is a self-paced learning tool for \\
\hline & & \\
\hline
\end{tabular}

This work is licensed under a Creative Commons Attribution 4.0 International License. 
How Factors of Personal Attitudes and Learning Environments Affect Gender Difference toward Mobile Distance Learning Acceptance Liaw and Huang

\begin{tabular}{|c|c|c|}
\hline & Regu05 & The learning steps are easy to regulate by myself. \\
\hline & Regu06 & $\begin{array}{l}\text { The learning contents are easy to regulate by } \\
\text { myself. }\end{array}$ \\
\hline \multicolumn{3}{|c|}{$\begin{array}{l}\text { Perceived Ease } \\
\text { of Use }\end{array}$} \\
\hline & Ease01 & The APP functions are easy to use. \\
\hline & Ease02 & The APP is easy to operate. \\
\hline & Ease03 & The content is easy to read. \\
\hline \multicolumn{3}{|l|}{$\begin{array}{l}\text { Perceived } \\
\text { Usefulness }\end{array}$} \\
\hline & Use01 & The interactive function is useful. \\
\hline & Use02 & The sharing function is useful. \\
\hline & Use03 & The social function is useful. \\
\hline & Use04 & I will use the APP for improving my learning. \\
\hline & Use05 & I will use the APP to find learning resources. \\
\hline & Use06 & I will use the APP to interact with other learners. \\
\hline \multicolumn{3}{|c|}{$\begin{array}{l}\text { Social Network } \\
\text { Interaction }\end{array}$} \\
\hline & Soci01 & The APP can enhance social learning effects. \\
\hline & Soci02 & The APP can improve social sharing. \\
\hline & Soci03 & The APP can assist social interaction. \\
\hline \multicolumn{3}{|l|}{$\begin{array}{l}\text { Behavioral } \\
\text { Acceptance }\end{array}$} \\
\hline & Acce01 & The APP can enhance learning efficacy. \\
\hline
\end{tabular}




\begin{tabular}{|l|l|l|}
\hline & Acce02 & The APP can enhance learning performance. \\
\hline & Acce03 & The APP can enhance learning motivation. \\
\hline & Acce04 & The APP can enhance learning satisfaction. \\
\hline & Acce05 & The APP can enhance learning enjoyment. \\
\hline
\end{tabular}

(C) Liaw and Huang

\section{Athabasca University $\mathbf{A}$}

(c) (7) 